\title{
An Analysis of Lord Jim From the Perspective of Salvation Motifs* $^{*}$
}

\begin{abstract}
SONG Zong-wei
Binzhou University, Binzhou, China

Conrad's attitude towards colonialism is always a focus among all the studies on Conrad. Most researchers believe that Conrad is against colonialism. And some other researchers hold that Conrad's attitude towards colonialism is ambivalent. This paper makes an analysis of Conrad's colonial attitudes and finds that in the novel Lord Jim, he not only represents his default attitude of colonialism but also reflects his pro-colonial attitude. In essence, the salvation motifs can be seen as a symbol of the deliverance of colonists.

Keywords: colonialism, salvation motifs, colonial attitude
\end{abstract}

\section{Introduction}

Joseph Conrad is one of the most important writers in British literature. Although English is not his mother tongue, he writes many classics in English. According to the themes, Conrad's novels can be divided into political novels, jungle novels, and marine novels. Sin and atonement are the most important concepts in salvation. If one wants to achieve the deliverance physically or spiritually, he should realize his sins first and then repents his wrongdoings. The process of the atonement of the protagonist Jim also shows Conrad's attitude to the colonialism.

\section{Human's Sins in Lord Jim}

\section{Jim's Two Wrongdoings}

Lord Jim, the masterpiece of Joseph Conrad, published in 1900, mainly tells the story of Jim. At an early age, Jim becomes greatly interested in the sea life and always imagines himself an almighty hero who does not fear dangers at all and can save other people. As a young man, he is very promising and has a very good future. Jim rises quickly through the ranks and becomes a chief mate soon. He is always dreaming about becoming a hero. However, it is just a daydream. He never faces any real dangers actually in life. When the chance comes finally, he makes a blunder. Jim is serving a vessel called Patna, carrying Muslim pilgrims to Mecca, when the ship strikes an underwater object and springs a leak. With a storm approaching, the crew abandons her and her passengers to their fate. Jim, not thinking clearly, abandons the ship with the rest of the crew. At the critical moment, Jim jumps into the lifeboat just because of the "natural impulse". This is Jim's first wrongdoing and it is

\footnotetext{
* Acknowledgements: This paper is supported by Research and Innovation Program for Young Teachers in Binzhou University (BZXYQNRW201601).

SONG Zong-wei, assistant, M.A., Foreign Language Department, Binzhou University, Binzhou, China.
} 
due to this wrong decision that Jim begins the rough torture psychological. However, out of everyone's expectation, Patna does not sink and the pilgrims are saved by French gunboat. Jim's natural jump makes him awfully tortured and guilty. From the beginning, Jim can realize the sins that he has made and he begins his difficult process of self-salvation. The whole and difficult process in which he realizes his sins and tries his best to make atonement can be regarded as the most important embodiment of the salvation motif in Lord Jim. Different from the skipper of the ship who escapes the moment danger comes, Jim never considers running away. It is because of the condemnation of his conscience that he decides to face the trial bravely. In Patusan jungle, Jim builds his dream but collapses finally. The local people regard Jim as a "lord" and Jim achieves his original dream there - he finds his love and wins the respect of the local people. However, Jim makes his second wrongdoing — releasing the local people's enemy and resulting in many deaths of the local people later.

The two wrong decisions make Jim desperate. Finally, Jim chooses death for his final atonement. From depravity to rebirth, Jim experiences the failure of resisting temptation in Patna. After the moral degeneration and moral discovery, Jim would rather choose death in order to achieve his salvation.

\section{Jim's Failure of Resisting Temptation}

Jim is raised in a Christian family. His father is a rural dean and the primitive simple atmosphere of the family exerts great effects on him. The family is like an Eden for Jim and he has a carefree childhood. The environment for Jim's growth environment is very similar to the environment of Adam and Eve. Adam and Eve live a carefree life in Eden at first. However, the failure of resisting of eating the fruits of knowledge makes human fall into the abyss of the sins. Similarly, Jim's jump from the ship makes him go out of "Eden" and fall into the "paradise lost".

Influenced by his father, Jim is very confident in himself and often imagines himself becoming a real hero and he will have no hesitation to save people if necessary. He dreams of doing heroic behaviors. For instance, Jim always imagines him a great hero who does not fear any dangers at all, no matter what happens. In a word, he is always lost in his imaginable heroic life. The best chance for him to realize his dream and ambition is to work at sea. Jim is born to be a suitable person engaged in sailing. Firstly, he comes from a personage, which is similar to many commanders of fine merchant-ships. Secondly, compared with his other parents, Jim shows great interests in the sea. He is sent to the training-ship school when a boy. From then, Jim is closely related to the marine life. At school, Jim soon masters some necessary skills and much sailing knowledge. Another advantage for Jim to be a good sailor is that he has steady head and excellent physique. Naturally, he is very popular with the crowded.

Jim always imagines fighting against with the hurricane. He even regards himself as a good example of devotion to responsibility and as unflinching as a hero described in a book. When Jim has received two years' training, he goes to the sea and engages in the sailing life. At first, Jim does not meet any adventure, making him little disappointed. For Jim, nothing is more enticing and disenchanting than the sailing life. What is more, he is sure that he must have good prospects because he seems to have all good qualities for a person who wants to make great achievements at sea. However, Jim is a person of moral conflict and mental crisis (LI, 2006, p. 46). Jim's inherent weakness and moral conflict determine that he can not fulfill his dream. At the beginning of the novel, Jim is noble and ambitious. The natural impulse lets Jim jump from the ship and it is this jump that makes him tortured in the rest of his life. Just like the ancestor of human Adam, who cannot resist themselves from eating the 
forbidden fruit, Jim cannot resist his life instinct, either. Jim can be seen as a Christian prototype (WANG, 2014, p. 81). Jim truly has many good qualities. After all, he is not Jesus; Jim cannot deal with the emergency and resist the life instinct. It is because of his jump that Jim gets involved in the sins. Different from the skipper, Jim chooses to face the trial. Jim's officer's certification is stripped. Jim starts to experience different kinds of tortures. Truly, as he recalls later, he jumps on the life boat finally, although he really does not attend to. The jump leaves Jim a lifetime disgrace, which cannot be erased.

On the surface, it seems that Jim makes a great sin of dereliction of duty. However, in essence, by using some artistic techniques, Conrad wins readers' sympathy and to a great extent, readers may forgive Jim. Conrad borrows the classical legend in Bible. Jim's failure of resisting of temptation is just similar to Adam and Eve. That is to say, Jim's sin of abandoning the ship can be acceptable. Conrad gives readers a feeling of forgiveness of Jim's behavior by using the similar sin made by human ancestors, Adam and Eve. This is the origin of guilt of all the mankind, not only Adam and Eve. Because of the original sin of human nature, Jim's decision seems reasonable and inevitable. (ZHANG, 2012, p. 16). Jim's failure of resisting the temptation shows Conrad's forgiveness of Jim. In this way, Conrad holds approval attitudes towards the representative of colonists, Jim.

\section{The Atonement in Lord Jim}

\section{Jim's Moral Dilemma}

The impulse of jump makes Jim involved in a moral dilemma. On the one hand, Jim really does not want to jump from the Patna and he is eager to save others' lives. But he becomes still and cannot do anything when the danger comes finally. As a result, Jim also jumps from the ship and even he does not know why he makes his wrong decision. On the other hand, Jim's escape also gets him involved in the accusations-from other crews and all walks of life. The moral dilemma makes Jim uneasy. From the talk with Marlow, it is evident that Jim feels very compunctious for his jump. By showing the human sins and Jim's moral dilemma, Conrad reveals his concern about the human nature.

For Jim, the wrong decision of abandoning the ship is a great shame for a ship officer. So when Jim has jumped from the ship, he does not look happy at all but feels puzzled instead. His reaction to the jump is totally from others. Other crews who flee away successfully look greatly excited, thinking that Patna must have sank into the sea. It should be pointed that Jim hesitates for some time before jumping from Patna. As soon as the ship hits the rock, Jim cannot do anything but stand still. He watches the ugly, disgusting, and the worried face of the sailors and feels suffered. He is obsessed by his behavior and it seems that nothing is more shameful than his behavior. He cannot understand and explain the reasons for his jump. Jim's jump and escape is unconscious, which can be illustrated by his suffering feelings.

Finally, Jim finishes his self-discovery. He knows his abandoning of the ship has made his reputation gone forever. Like other crews who jump from Patna, Jim could have fled to a new place and lived a carefree life. However, Jim does not do that but chooses to face the trial. Due to his painful memories and different kinds of rumors, Jim makes himself sink into self-reproach. The self moral condemnation makes Jim fall into despair and have a sense of guilty, which pays the foundation of his atonement.

\section{Jim's Moral Discovery}

The moral discovery is an important step for Jim to make atonement, which is a significant embodiment of 
the salvation motif in Lord Jim. It is because of the moral discovery that makes Jim understand his sins clearly and makes him do what he can to make atonement for his sins.

When Jim is offered money and advised to flee from the inquiry, Jim refuses flatly. Jim is tortured by different kinds of rumors and the self-reproach. Jim realizes his moral discovery. Jim's self-conscious moral discovery is the psychological foundation for his atonement. Jim's mentality is rather complicated when he has jumped from the ship and he admits his jump but cannot believe he has made crimes psychologically (ZHAN, 1991, p. 141). Jim's moral judgment and moral discovery are the main reasons to realize his wrong behaviors.

Then he finds a water-clerk job with Marlow's help. Jim becomes ambitious and tells Marlow that he will be likely to become a hero and achieve much success again. It seems that Jim has forgotten his jump of the ship. However, being afraid of others knowing his past, he gives up the water-clerk job and continues to change jobs again and again. This fully illustrates that Jim realizes his self-discovery and wants to get rid of his shameful acts.

Jim rejects Marlow again and does not adopt the suggestion that he go to America. Out of sympathy, Marlow is determined to ask Stein to help Jim. Stein considers Jim as "romantic". The moment he gets Jim's story from Marlow, Stein suggests that they send Jim to Patusan, a very remote territory where he has a trading post. Jim accepts the help delightfully with the hope of becoming a real hero there. After some unexpected things, Jim finally reaches Patusan.

Patusan is a primitive and isolated place which no one who once lived in a civilized society would be willing to go to. In order to make up his sins, Jim chooses to live there and does his best to help the natives. For Jim, the new place is the best place to achieve all his dreams and it is this place that marks the beginning of Jim's new life. It is also in this place that Jim finds his love and gets friend. The new life brings Jim great hope of the future. In Patusan, Jim becomes a respectable "lord" from a common person, which illustrates his great success. Jim also gets trust of Doramin, with the silver ring given by Stein. Everything goes smoothly in Patusan and successes come continually. Jim defeats Ali and becomes a real hero in the new place. Jim shows his brave and courage in the flight in which he keeps on rushing down and climbing like a squirrel. He encourages the local people to fight bravely. One of the important reasons for Jim to work so hard and fight so bravely is that he wants to "get it all back" and makes up for the sins that he has made before. The process of the pursuing his dream is also a chance for Jim to make up for his first wrongdoing. Moral discovery makes Jim pursue his dream without hesitation.

Jim's efforts pay off in Patusan finally. For example, he finds his true love and marries Jewel; he gets the true friendship and becomes the best friend of Dain Waris; he becomes the "lord" of the local, a spiritual hero and becomes the true ruler of Malays. Local people regard Jim as their great hero because of his heroic behaviors. In Patusan, Jim is the only hero and has supreme command over everything. Nobody can be compared with Jim. Because of the moral discovery and the desire to make atonement for his first wrongdoing, Jim always tries his best to be friendly to others in Patusan.

All the success achieved in Patusan show that Jim seems to have finished all his dreams and gets some comfort psychologically. Guided by predatory colonial ethics, European settlers launch worldwide colonial wars and colonize the relatively less-developed areas and they take the colonial exploitation for granted (ZHU, 2006, p. 185). The ethics of the Victorian era also emphasizes that people should conform to responsibility. The complicated ethics gives Conrad great influences. For instance, in Lord Jim, on the one hand, Jim is satisfied with his success of the local natives; on the other hand, Jim feels guilty and tortured when he makes wrongdoings. 


\section{Jim's Death for Eternal Life}

It seems that the shame of jumping from the Patna has gone. Jim also argues that he has won everything in Patusan. However, Jim's newly-rebuilt dream collapses again when he makes the second wrongdoing. When Brown and his companions come to Patusan and make sneak attacks to Jim and the natives, Jim makes negotiations with him. Jim wants to know the reason of Brown's coming to the Patusan but Brown only replies very simply, "Hunger". When Jim gets the answer, he becomes startled and hesitated. Out of pity, Jim becomes indecisive and he believes what Brown says.

Brown dares to do and say everything he wants. Brown asks Jim what he really wants to do in Patusan and it is this question that makes Jim realizes that he has cheated himself and has been living in a lie. It also makes Jim believes that even Brown is honest about his real motives. Brown tells the truth which gives Jim a feeling that if he kills Brown, he will make another lie and he will still live in the lie forever. Out of hesitation, Jim lets Brown go and this wrong decision directly leads to another great mistake. Later, Brown attacks the natives in Patusan and causes a lot of deaths. To some extent, the aftermath of his second wrongdoing is more serious than the first one.

After all, Jim is a common; he makes the wrong decision and causes great loss at critical moment. The desire to "get it all back" makes him live in the dream. Jim's second wrongdoing causes the death of Dain Waris, the son of the native leader, and Jim's best friend. Up to now, the newly-built dream collapses completely and Jim cannot forgive himself in his inner heart. The second wrongdoing makes Jim fall from the heaven to the hell. The complete collapse of his dream and the sense of guilt force Jim to end his life.

Jim's death is not a compromise but a moral rebirth. Jim cannot accept his mistake again and the death is the best way to illustrate his confession. The death is not the ending of his life but the rebirth of his moral. The moral discovery and death are the embodiments of Jim's atonement. His death makes him become a moral hero, so his death can be regarded as the moral rebirth. In Lord Jim, Conrad mentions Jim "one of us" many times. Even though, Jim makes sins and is accused of making sins of dereliction of duty. Jim is still different from others. He has an intense inner struggling before abandoning the ship. He tells himself many times that he cannot do the shameful behavior. He wants to save the people in Patna.

Although Jim makes great sins, he can be also regarded as a good image at that time in that he does his best to atone for his sins willingly. Jim's death can be regarded as a rebirth. As a great writer, Conrad shows that human should accept the punishment for the sins. He also shows us as long as human can repent sincerely, they can get a new life; the soul can be also saved. This is the spiritual salvation that is embodied in Lord Jim.

\section{Conclusion}

To some extent, the salvation motifs showing Conrad's attitudes towards colonialism in that novels always implicate the writer's attitudes. The salvation motifs are just a way for Conrad to show his pro-colonial attitude. Also, by making the protagonists achieve atonement, Conrad also shows that he is still confident in human.

\section{References}

LI, W. P. (2006). Moral revelation and didacticism: The characterization in Joseph Conrad's jungle fiction. Journal of Zhejiang Normal University (Social Science), 31(3), 46. 
WANG, J. B. (2014). On the Study of biblical prototypes of the characters in Lord Jim. Journal of Jilin Institute of Chemical Technology, 31(6), 81.

ZHAN, S. K. (1991). Lord Jim and Conrad's artistic pursuit and moral exploration. Journal of Xiamen University (Arts \& Social Science), 3, 141.

ZHANG, B. (2012). From depravity to rebirth: An archetypal interpretation of moral theme in Lord Jim (Master thesis, Jilin University).

ZHU, Y. D. (2006). The dual property of the imperialistic language of Joseph Conrad. Journal of Guangxi University for Nationalities, 7, 185. 